Omówienia 



\section{Holokaust w niemieckiej literaturze naukowej ostatnich pięciu lat}

W niemieckich badaniach historycznych nad ludobójstwem Żydów europejskich, będących z kolei częścią badań poświęconych narodowemu socjalizmowi ${ }^{1}$, można wyróżnić obecnie dwa - w dużym stopniu oddzielne - aspekty: przede wszystkim to „zadośćuczynienie” za nazistowskie bezprawie, ściganie zbrodni hitlerowskich, jak również podejście do zagadnienia prześladowania Żydów przez pryzmat polityki pamięci, które to analizy cieszą się niezmienną popularnością i rozwijają się często wokół coraz nowszych metodologicznie i ambitniej formułowanych problemów badawczych² ${ }^{2}$ Odnośnie do wydarzeń sprzed roku 1945 uwaga historyków ponownie dzieli się na dwa, geograficznie i czasowo zwykle wyraźnie oddzielne obszary; ustalenia faktograficzne odgrywają w obydwu kierunkach ważną rolę. Z jednej strony są to badania nad losem niemieckich Żydów, przedstawianym obecnie głównie na przykładzie wywłaszczeń i deportacji do 1941 r. Z drugiej strony przede wszystkim młodzi naukowcy skupiają się w swoich dysertacjach na wydarzeniach wojennych i okupacyjnych w Europie Wschodniej: szeroko korzystając z lokalnych badań i archiwów, analizują w szczególności postępowanie sprawców, o wiele rzadziej zajmując się natomiast losem ofiar.

W 2006 r. Jürgen Hensel zdawał w tym miejscu relację ze stanu niemieckich badań nad Holokaustem³. Od tego czasu upłynęło pięć lat, w czasie których na

\footnotetext{
${ }^{1}$ Najlepszy zarys nakreślił Michael Wildt, Die Epochenzäsur 1989/90 und die NS-Historiographie, „Zeithistorische Forschungen” 2008, nr 5, s. 349-371.

${ }^{2}$ Zob. najnowsze tomy zbiorowe: Volkhard Knigge, Norbert Frei, Verbrechen erinnern. Die Auseinandersetzung mit Holocaust und Völkermord, München: C.H. Beck, 2002; Die Praxis der Wiedergutmachung. Geschichte Erfahrung und Wirkung in Deutschland und Israel, red. Norbert Frei i in., Göttingen: Wallstein, 2009. Obszerny przegląd problematyki w: Constantin Goschler, Schuld und Schulden. Die Politik der Wiedergutmachung für NS-Verfolgte seit 1945, Göttingen: Wallstein, 2005. Na temat ścigania zbrodni nazistowskich: Vom Recht zur Geschichte. Akten aus NS-Prozessen als Quellen der Zeitgeschichte, red. Andreas Wirsching i in., Göttingen: Vandenhoeck \& Ruprecht, 2009; Das Gericht als Tribunal. Oder: Wie der NS-Vergangenheit der Prozess gemacht wurde, red. Georg Wamhof, Göttingen: Wallstein, 2009. Wkrótce ukaże się: Katrin Stoll, Strafverfahren gegen ehemalige Angehörige der Sicherheitspolizei für den Bezirk Bialystok, Berlin: Metropol, 2011.

${ }^{3}$ Jürgen Hensel, Niemcy 2005, „Zagłada Żydów. Studia i Materiały” 2006, nr 2, s. 543-553.
} 
rynku pojawiło się wiele nowości wydawniczych. Przedstawię tu najważniejsze prace zbiorowe i monografie, uwzględniając artykuły tylko w wyjątkowych wypadkach. Prace dotyczące okresu powojennego nie będą brane pod uwagę ze względu na brak miejsca, odnosi się to również do zagadnienia Holokaustu w Europie Zachodniej, obecnego przede wszystkim w publikacjach Instytutu Historii Współczesnej (Institut für Zeitgeschichte) w Monachium. Tematem niniejszej prezentacji jest literatura naukowa poświęcona wydarzeniom w okupowanej przez Niemcy Europie Wschodniej, dla których decydujące warunki wstępne stworzono na terenie Rzeszy ${ }^{4}$.

Centralnym dziełem w badaniach nad narodowym socjalizmem i Holokaustem było w ostatnich latach Państwo Hitlera autorstwa Götza Aly’ego ${ }^{5}$. Z ogromnym wyczuciem interesujących i nieopracowanych problemów, a zarazem umiejętnością stawiania ostrych tez Aly tłumaczy aprobatę dla dyktatury motywacją materialną. „Wspólnota narodowa” (Volksgemeinschaft) funkcjonowała, jego zdaniem, tak dobrze także dlatego, że wielu Niemców czerpało z tego korzyści, między innymi ze względu na to, iż deportacja Żydów z Rzeszy i ich eksterminacja na podbitych terenach przynosiła wymierne profity finansowe. Aly’ego atakowano za jego nie zawsze przekonująco udokumentowane twierdzenia, ponieważ przecenił rzeczywiste znaczenie ekonomiczne tego łupieżczego najazdu, zarówno w wymiarze ogólnym, jak również w jego następstwach w Rzeszy ${ }^{6}$.

Książka ta zainspirowała jednak kolejnych historyków oraz nagłośniła prowadzone, a wówczas stopniowo wygasające badania nad tzw. aryzacją, czyli dokonywanym głównie w Rzeszy zaborem i redystrybucją żydowskiego mienia. Prace zbiorowe na ten temat ukazały się w Turyngii ${ }^{7}$, ale przede wszystkim w takich miastach, jak Lipsk ${ }^{8}$, Berlin ${ }^{9}$ czy Monachium ${ }^{10}$. W przypadku „stolicy ruchu nazistow-

\footnotetext{
${ }^{4}$ Przywoływana tutaj literatura jest niemal w pełni dostępna w Niemieckim Instytucie Historycznym w Warszawie.

${ }^{5}$ Götz Aly, Hitlers Volksstaat. Raub Rassenkrieg und nationaler Sozialismus, Frankfurt am Main: Fischer, 2005 (wyd. polskie: Państwo Hitlera, tłum. Wojciech Łygaś, Gdańsk: Finna, 2006).

${ }^{6}$ Por. przykładowo recenzje w czasopiśmie online „sehepunkte”, http://www.sehepunkte.de/2005/07/forum/goetz-aly-hitlers-volksstaat-raub-rassenkrieg-und-nationaler-sozialismus-frankfurt-am-2005-98/, dostęp 14 X 2011 r.

${ }^{7}$ Monika Gibas, „Arisierung” in Thüringen. Ausgegrenzt ausgeplündert ausgelöscht, Leipzig: Leipziger Universitätsverlag, 2009.

${ }^{8}$ „Arisierung” in Leipzig. Annäherung an ein lange verdrängtes Kapitel der Stadtgeschichte der Jahre 1933 bis 1945, red. Monika Gibas, Leipzig: Leipziger Universitätsverlag, 2007.

${ }^{9}$ „Arisierung” in Berlin, red. Christof Biggeleben, Berlin: Metropol, 2007.

${ }^{10}$ Entehrt, ausgeplündert, arisiert. Entrechtung und Enteignung der Juden, red. Andrea Baresel-Brand, Angelika Baumann, Magdeburg: Koordinierungsstelle für Kulturgutverluste, 2005. Na ten temat, łącznie z zagadnieniem restytucji, zob. Ingo Köhler, Die „Arisierung” der Privatbanken im Dritten Reich. Verdrängung, Ausschaltung und die Frage der Wiedergutmachung, München: C.H. Beck, 2008.
} 
skiego" zaprezentowano, jak żydowskie przedsiębiorstwa zwykle jeszcze w latach trzydziestych otrzymywały nowych i przede wszystkim aryjskich właścicieli, bogacących się na prześladowaniach i pozbawieniu praw ich współmieszkańców.

Uniwersytet w Monachium jeszcze przed publikacją książki Aly’ego przystąpił do realizacji projektu badawczego, którego tematem była rola państwowej administracji finansowej. Udokumentowano na przykładach, z jaką biurokratyczną wydajnością, a zarazem perfidią urzędnicy realizowali odbieranie żydowskiego majątku ${ }^{11}$ i za pomocą niezliczonych podatków specjalnych, a właściwie dyskryminacji podatkowej prowadzili systematyczną grabież ${ }^{12}$. Podatek od ucieczki z Rzeszy (Reichsfluchtsteuer), na podstawie którego ściągano od emigrujących Żydów 25 procent ich majątku z roku 1938*, jest tego najdobitniejszym przykładem, a nie oznaczał on bynajmniej, że pozostałą część Żydzi mogli po prostu ze sobą zabrać za granicę: uchodźcy tracili przeważnie 90 procent swojego mienia.

W celu zapewnienia prawidłowej procedury od strony formalnoprawnej nawet w przypadku deportacji Żydów do leżącego na terenie Rzeszy KL Auschwitz zarządzano uprzednio odebranie im obywatelstwa.

Deportacje na Wschód stanowią kolejny priorytet w badaniach nad Holokaustem ostatnich pięciu lat. Diana Schulle i Alfred Gottwald już w 2005 r. opublikowali zestawienie wszystkich transportów kolejowych z Niemiec do gett i obozów zagłady w okupowanej Europie Wschodniej ${ }^{13}$, a w 2008 r. otwarto szeroko komentowaną wystawę Kolei Niemieckich zatytułowaną „Pociągi specjalne ku śmierci” („Sonderzüge in den Tod”). Kontrowersje budziła nie tyle treść projektu, w którym niezwykle rzeczowo i obiektywnie przedstawiono udział kolei Rzeszy w masowym mordzie na Żydach ${ }^{14}$, ile raczej wykorzystanie tej ruchomej wystawy - z jednej strony zaplanowano pokazanie jej w całych Niemczech, z drugiej zaś prezentowano ją na dworcach tylko z lokalnej inicjatywy i ustawiano z zażenowaniem na uboczu.

Nieustanne zainteresowanie losem dawnych współmieszkańców doprowadziło jednak w wielu miastach do stworzenia własnych wystaw, a przede wszystkim ksiąg pamięci, dokumentujących deportacje, nazwiska wywiezionych, a często

${ }^{11}$ Christiane Kuller, Finanzverwaltung und Judenverfolgung. Die Entziehung jüdischen Vermögens in Bayern während der NS-Zeit, München: C.H. Beck, 2008.

${ }^{12}$ Axel Drecoll, Der Fiskus als Verfolger. Die steuerliche Diskriminierung der Juden in Bayern 1933-1941/42, München: Oldenbourg, 2009. Por. dla Berlina Martin Friedenberger, Fiskalische Ausplünderung. Die Berliner Steuer- und Finanzverwaltung und die jüdische Bevölkerung 1933-1945, Berlin: Metropol, 2008.

*Podatek ten został wprowadzony w 1931 r., w czasach wielkiego kryzysu. W 1938 r. jego pobór przyniósł najwięcej dochodów państwu. Obowiązywał do 1953 r. (przyp. red.).

${ }^{13}$ Alfred B. Gottwaldt, Diana Schulle, Die „Judendeportationen” aus dem Deutschen Reich von 1941-1945. Eine kommentierte Chronologie, Wiesbaden: Marix, 2005.

${ }^{14}$ Zob. na ten temat Thomas Kuczynski, Dem Regime dienen - nicht Geld verdienen. Zur Beteiligung der Deutschen Reichsbahn an Deportationen und Zwangsarbeit während der NS-Sicht. Einige Überlegungen aus ökonomischer Sicht, „Zeitschrift für Geschichte” 2009, nr 57, s. 510-528. 
również przykładowe biografie. Wzorcowym tego przykładem jest publikacja pod redakcją Ingo Loosego poświęcona Żydom berlińskim w getcie łódzkim (Ghetto Litzmannstadt), która w 2009 r. ukazała się również w polskim przekładzie ${ }^{15}$. Podobne opracowania opublikowano przykładowo dla Frankfurtu ${ }^{16}$, Düsseldorfu - także w tym przypadku opisano transporty do getta łódzkiego ${ }^{17}$, czy też Bremy ${ }^{18}$.

O ile finansowe wzbogacenie w ramach aryzacji i wywożenie Żydów na Wschód może tymczasem uchodzić za poniekąd dobrze opisane, o tyle reakcje na bezpośrednią zagładę - z wyjątkiem studiów poświęconych problematycznym z metodologicznego punktu widzenia listom poczty polowej ${ }^{19}$ - są o wiele mniej znane. Prekursorskie studium Petera Longericha zostało omówione w tym miejscu już przed pięcioma laty ${ }^{20}$, a od tego czasu ukazały się kolejne prace pokazujące, jaką wiedzę o Holokauście mają Niemcy ${ }^{21}$.

W renomowanym „Vierteljahrsheft für Zeitgeschichte” od kilku lat trwa dyskusja na temat tego, kiedy członkowie wojskowego ruchu oporu dowiedzieli się o Holokauście i jak nań zareagowali. Johannes Hürter w 2004 r. przekonująco dowodził, że późniejsi konspiratorzy już latem $1941 \mathrm{r}$. wiedzieli o masowych mordach dokonywanych przez Einsatzgruppen na terenie Związku Radzieckiego, ale moralne zastrzeżenia wyrazili dopiero kilka miesięcy później, w obliczu widocznych już w pełni rozmiarów wojny eksterminacyjnej ${ }^{22}$. Zaprezentowane przez Hürtera dokumenty napotkały sprzeciw w głównej mierze starszych historyków i publicystów, którzy krytykowali te fakty i bronili, niekiedy w bardzo osobistym tonie, prawości opozycji wojskowej - obawiając się swego rodzaju strącenia z piedestału ich narodowo-konserwatywnych bohaterów. Rozwinęła się - w dużym stopniu bezowocna

${ }^{15}$ Berliner Juden im Getto Litzmannstadt 1941-1944. Ein Gedenkbuch, red. Ingo Loose, Berlin: Stiftung Topographie des Terrors, 2009 (wyd. polskie: Żydzi berlińscy w Litzmannstadt getto 1941-1944. Księga pamięci, red. Ingo Loose, tłum. Maria Goldstein, Łódź: Archiwum Państwowe, 2009).

16 „Und keiner hat für uns Kaddisch gesagt...”. Deportationen aus Frankfurt am Main 1941-1945. Begleitpublikation zur gleichnamigen Ausstellung des Jüdischen Museums der Stadt Frankfurt am Main, red. Fritz Backhaus, Frankfurt am Main: Stroemfeld, 2005.

${ }^{17}$ Düsseldorf - Getto Litzmannstadt 1941, red. Angela Genger, Essen: Klartext, 2010.

${ }^{18}$ „.... sind Sie für den geschlossenen Arbeitseinsatz vorgesehen...”. „Judendeportationen” von Bremerinnen und Bremern während der Zeit der nationalsozialistischen Gewaltherrschaft, red. Günther Rohdenburg, Manfred Ernst, Bremen: Staatsarchiv, 2009.

${ }^{19}$ Sven Oliver Müller, Deutsche Soldaten und ihre Feinde. Nationalismus an Front und Heimatfront im Zweiten Weltkrieg, Frankfurt am Main: Fischer, 2007.

${ }^{20}$ Peter Longerich, „Davon haben wir nichts gewusst!”. Die Deutschen und die Judenverfolgung 1933-1945, München: Siedler, 2006 [Hensel, Niemcy..., s. 550].

${ }^{21}$ Zob. omówienie debaty w: Hans Mommsen, Der Holocaust und die Deutschen. Aktuelle Beiträge zu einer umstrittenen Frage, „Zeitschrift für Geschichte” 2008, nr 56, s. 844-853.

22 Johannes Hürter, Auf dem Weg zur Militäropposition. Treckow, Gersdorff, der Vernichtungskrieg und der Judenmord. Neue Dokumente über das Verhältnis der Heeresgruppe Mitte zur Einsatzgruppe B im Jahr 1941, „Vierteljahrshefte für Zietgeschichte” 2004, nr 52, s. $527-562$. 
- debata, której poświęcono wiele miejsca, ale w której nie zdołano obalić argumentów Hürtera, popartych dodatkowo przez Felixa Römera ${ }^{23}$.

W odróżnieniu od tej niewielkiej elity, wokół której toczyła się dyskusja, obiektem badań Bernwarda Dörnera były recepcja i stosunek wszystkich Niemców do Holokaustu ${ }^{24}$. Dochodzi on - argumentując niekiedy dość ogólnikowo - do wniosku, że eksterminacja nie spotykała się bynajmniej z powszechną aprobatą, ale często z zastrzeżeniami. Dörner stwierdza, że o ile część Niemców rzeczywiście aprobowała ludobójstwo, o tyle większość zachowywała wobec niego milczenie, jak najbardziej mając pewne wyobrażenie o dokonywanym masowym mordzie, nawet jeśli jego skala rzadko kiedy była w pełni widoczna. Niemniej ogół przeważnie nie chciał przyjąć go do wiadomości, lecz zaprzeczał faktom bądź je wypierał.

Podobne wnioski prezentują także Frank Bajohr i Dieter Pohl25, ale ich podejście do problemu jest odmienne. Pokazują, jak po 1933 r. pomiędzy reżimem a społeczeństwem zawiązywał się antysemicki konsensus, który po przełomie pod Stalingradem przemienił się w rodzaj strategii wyrównania strat: według niej to Żydzi mieli być odpowiedzialni za wojnę, a do tego również Niemcy musieli ponieść liczne ofiary; nie przeszkadzało przy tym, że mimo przyjętych założeń masowe mordy jakoś kłóciły się z moralnym odczuciem narodu i nie były niczym, z czego można było być dumnym - akcja „1005”, czyli ekshumacja zwłok i ich spalanie ${ }^{26}$, żeby zatuszować czyny, jest tego najbardziej znamiennym dowodem. Holokaust nie odgrywał jednak ważnej roli w propagandzie wojennej ani dla aliantów, ani dla nazistów; przyczyną połowicznego tylko ścigania sprawców była, zdaniem badaczy, powszechna zgoda na przemilczenie i na nowy początek, wkrótce po $1945 \mathrm{r}$. podzielana także przez zwycięskie mocarstwa.

W tym kontekście ujawniają się istotne następstwa „wspólnoty narodowej”, owego propagowanego przez reżim społeczeństwa „Aryjczyków”, które, wewnętrznie spójne z powodu wyimaginowanych wspólnych cech rasowych, miało solidarnie występować przeciwko wszystkim stojącym poza wspólnotą. Ta perspektywa badawcza przeżywała w latach ubiegłych prawdziwy boom ${ }^{27}$, przy czym ostatnio Ian Kershaw wskazał także granice tej interpretacji ${ }^{28}$. Centralne znaczenie

${ }^{23}$ Chociaż debata trwała do 2010 r., najważniejsze argumenty padły w 2006 r. Por. Johannes Hürter, Felix Römer, Alte und neue Geschichtsbilder von Widerstand und Ostkrieg. Zu Hermann Gramls Beitrag „Massenmord und Militäropposition”, „Vierteljahrshefte für Zietgeschichte" 2006, 54, s. 301-322.

${ }^{24}$ Bernward Dörner, Die Deutschen und der Holocaust. Was niemand wissen wollte, aber jeder wissen konnte, Berlin: Propyläen, 2007.

${ }^{25}$ Frank Bajohr, Dieter Pohl, Der Holocaust als offenes Geheimnis. Die Deutschendie NS-Führung und die Alliierten, München: C.H. Beck, 2006.

${ }^{26}$ Jens Hoffmann, „Das kann man nicht erzählen”. „Aktion 1005” - Wie die Nazis die Spuren ihrer Massenmorde in Osteuropa beseitigten, Hamburg: KVV Konkret, 2008.

${ }^{27}$ Najlepsze omówienie w: Volksgemeinschaft. Neue Forschungen zur Gesellschaft des Nationalsozialismus, red. Frank Bajohr, Michael Wildt, Frankfurt am Main: Fischer, 2009.

${ }^{28}$ Ian Kershaw, „Volksgemeinschaft”. Potenzial und Grenzen eines neuen Forschungskonzepts, „Vierteljahrshefte für Zietgeschichte” 2011, nr 59, s. 1-17. 
w omawianej koncepcji ma jeden $\mathrm{z}$ aspektów inkluzji i ekskluzji, podkreślający skonsolidowanie wspólnoty (dosł. uwspólnotowienie - Vergemeinschaftung) „Aryjczyków” kosztem wszystkich pozostałych, wykluczonych „obcych dla wspólnoty”, do których w pierwszej kolejności należeli Żydzi. Jak pokazują najnowsze opracowania, takie podejście do problemu może daleko prowadzić i otworzyć nowe perspektywy badań nad Trzecią Rzeszą i jej zbrodniami ${ }^{29}$. Zdumiewające jednak, że w kontekście wspólnoty narodowej nie poddano jeszcze studiom kwestii mieszkających przede wszystkim w Czechach i Polsce volksdeutschów, chociaż to właśnie w ich przypadku inkluzja kosztem lokalnej ludności - a przede wszystkim Żydów - była posunięta bardzo daleko ${ }^{30}$.

Ekskluzja pod panowaniem narodowego socjalizmu oznacza w wielu wypadkach śmierć, przeważnie w jednym z niezliczonych obozów, którymi Niemcy pokryli kontynent. Rozprawy na ten temat i katalogi poświęcone różnym miejscom pamięci są nieprzeliczone. W przeważającej większości badania koncentrują się na ofiarach nieżydowskich oraz na obozach na terenie Rzeszy, a takie prace, jak Barbary Schwindt na temat Majdanka, należą do wyjątków ${ }^{31}$. Na szczęście dwoje zaangażowanych redaktorów - Wolfgang Benz i Barbara Distel - opublikowało tymczasem 9-tomowe wydawnictwo poświęcone wszystkim obozom koncentracyjnym i obozom zagłady, z podobozami włącznie, niemal zawsze pozyskując do opracowania ich dziejów uznanych specjalistów. Publikacja ta, nosząca tytuł Der Ort des Terrors (Miejsce terroru), pozostanie na wiele lat nieodzownym wzorcowym dziełem, zawierającym nie tylko istotne fakty, lecz także literaturę i źródła ${ }^{32}$.

Rangą przewyższa ją jedynie rozpoczęta niedawno przez Archiwum Federalne (Bundesarchiv) i Instytut Historii Współczesnej edycja Verfolgung und Ermordung der europäischen Juden durch das nationalsozialistische Deutschland 1933-1945 (Prześladowanie i wymordowanie Żydów europejskich przez narodowosocjalistyczne Niemcy 1933-1945), obejmująca w 16 tomach wybór dokumentów kluczowych dla Holokaustu w całej Europie. Zamierzeniem wydawców jest przedstawienie możliwie wszystkich aspektów eksterminacji Żydów na podstawie źródeł pisanych pochodzących od sprawców, ofiar oraz świadków, wszystkich w przekładzie na język niemiecki. W 2011 r. ukazał się opracowany przez Klausa-Petera Friedricha tom poświęcony Generalnemu Gubernatorstwu w okresie od 1939 do

${ }^{29}$ Michael Wildt, Volksgemeinschaft als Selbstermächtigung. Gewalt gegen Juden in der deutschen Provinz 1919 bis 1939, Hamburg: Hamburger Edition, 2007.

${ }^{30}$ Pierwszym takim studium jest Stephan Lehnstaedt, Volksdeutsche in Tschenstochau. Germanisierungspolitik für Täter, Profiteure und Zuschauer des Holocaust, „Zeitschrift für Ostmitteleuropa-Forschung" 2008, nr 57, s. 425-452 (wersja w języku polskim: Niemcy etniczni w Czestochowie. Narodowosocjalistyczna polityka germanizacyjna dla sprawców, beneficjentów i obserwatorów holocaustu, „Studia Claromontana” 2010, nr 28, s. 641-675).

${ }^{31}$ Barbara Schwindt, Das Konzentrations- und Vernichtungslager Majdanek. Funktionswandel im Kontext der „Endlösung”, Würzburg: Königshausen \& Neumann, 2005.

${ }^{32}$ Der Ort des Terrors. Geschichte der nationalsozialistischen Konzentrationslager, t. 1-9, red. Wolfgang Benz, Barbara Distel, München: C.H. Beck, 2006-2009. 
jesieni 1941 r. ${ }^{33}$ Walorem tej publikacji jest mądre wprowadzenie, w którym nakreślono historię Żydów w Polsce przed rokiem 1939 oraz pierwsze dwa lata okupacji. Wybrane teksty skrupulatnie skomentowano, w przypisach zamieszczono mnóstwo informacji, zwłaszcza w odniesieniu do osób, i szczegółowe wskazania, na przykład zarządzeń, na które dane pismo się powołuje.

O ile w badaniach prowadzonych w Republice Federalnej Niemiec wyraźny nacisk położono na kwestię sprawców, o tyle historia ofiar, kolaborantów czy w najlepszym tego słowa znaczeniu historia zintegrowana, łącząca nie tylko te trzy grupy, lecz uwzględniająca także pozostałą miejscową ludność, nadal pozostaje w sferze postulatów badawczych. W dalszym ciągu dominuje przedstawianie struktur [sprawców] i prześladowań w konkretnym regionie, na przykład w omówionym już przez Jürgena Hensla pionierskim studium Michaela Albertiego o tzw. Kraju Warty (Reichsgau Wartheland) ${ }^{34}$. Na temat Generalnego Gubernatorstwa ukazały się $\mathrm{W}$ omawianym okresie dwie książki poświęcone dystryktowi radomskiemu ${ }^{35}$, które wspólnie dają imponujący obraz polityki okupacyjnej. Jacek Andrzej Młynarczyk, którego analiza nie jest ograniczona jedynie do opisu struktur, łączy perspektywę ofiar, świadków i beneficjentów Zagłady, dając tym samym kompleksowy wgląd w powszechne postrzeganie ludobójstwa i przyjmowane wobec niego postawy. Książka jest źródłem ważnych inspiracji w odniesieniu do zagadnień, których przyszła analiza - w zakresie badań nad Holokaustem - może jeszcze okazać się nad wyraz owocna.

W całkiem odmienny sposób czyni to także Ingo Loose, zajmujący się aryzacją własności w Polsce przez niemieckie banki ${ }^{36}$. Jego utrzymane na gruncie ekonomicznym studium pokazuje, że Holokaustu nie można wyjaśnić bez uwzględnienia motywów i skutków gospodarczych. W świetle jego ustaleń bez instytucji kredytowych nie byłoby możliwe wywłaszczenie polskiego i żydowskiego sektora prywatnego, co z kolei oznaczałoby dla narodowych socjalistów zupełnie inny dostęp do kraju. Ludobójstwo nie było fenomenem oderwanym od pozostałych wydarzeń, ale

${ }^{33}$ Die Verfolgung und Ermordung der europäischen Juden durch das nationalsozialistische Deutschland 1933-1945, t. 4: Polen, September 1939-Juli 1941, red. Klaus-Peter Friedrich, München: Oldenbourg, 2011. Już wcześniej ukazały się tomy 1 i 2, dokumentujące sytuację w Rzeszy Niemieckiej w latach 1933-1939.

${ }^{34}$ Michael Alberti, Die Verfolgung und Vernichtung der Juden im Reichsgau Wartheland. 1939-1945, Wiesbaden: Harrassowitz, 2006 [Hensel, Niemcy..., s. 549].

${ }^{35}$ Robert Seidel, Deutsche Besatzungspolitik in Polen. Der Distrikt Radom 1939-1945, Paderborn-München: Schöningh 2006; Jacek Andrzej Młynarczyk, Judenmord in Zentralpolen. Der Distrikt Radom im Generalgouvernement 1939-1945, Darmstadt: Wissenschaftliche Buchgesellschaft, 2007.

${ }^{36}$ Ingo Loose, Kredite für NS-Verbrechen. Die deutschen Kreditinstitute in Polen und die Ausraubung der polnischen und jüdischen Bevölkerung 1939-1945, München: Oldenbourg, 2007. 
włączało się w dynamikę panowania i wojny - i tylko w tym kontekście należy je rozumieć. Uwidaczniają to również dwie publikacje zbiorowe Niemieckiego Instytutu Historycznego w Warszawie, konfrontujące nazistowskie i sowieckie panowanie w Polsce ${ }^{37}$; Holokaust był najbardziej ekstremalną formą ludobójczej przemocy, ale właśnie poznanie jego szerszego kontekstu zawiera jeszcze duży potencjał interpretacyjny.

Obiecująco wyglądają pod tym względem studia porównawcze, które wiążą się jednak z dużym nakładem pracy. Nauka historyczna odcięła się jednak wyraźnie od diachronicznej komparatystyki i odrzuciła teorie przedstawiające masowy mord na Żydach w pewnej ciągłości z wojnami kolonialnymi i dokonującymi się wówczas ludobójstwami ${ }^{38}$. Holokaust w swoim wymiarze i systematyce nie jest wytłumaczalny na gruncie idei kolonializmu, choćby niektóre metody badawcze ze studiów nad ludobójstwem w różnych częściach świata miały się okazać tu przydatne. Zważywszy jednak na fakt, że nawet wiedza na temat wydarzeń z lat 1939-1945 nadal jest pełna luk, należy przyjąć z radością porównania, szczególnie synchroniczne. Ważny krok w tym kierunku uczynili Wolf Gruner i Jörg Osterloh publikacją o prześladowaniach Żydów na terenach włączonych do Rzeszy ${ }^{39}$. Do opracowania badanych zagadnień w odniesieniu do wszystkich regionów, które od ponownego przyłączenia Kraju Saary w 1935 r. zostały wcielone do terytorium Rzeszy, pozyskali kompetentnych współpracowników, którzy z jednej strony dla każdego obszaru przedstawili przegląd stanu badań, a z drugiej strony zaprezentowali własne ustalenia. Wszystkie artykuły koncentrują się na zasadniczych zagadnieniach, tak że czytelnik otrzymuje przydatną pomoc w postaci dzieła referencyjnego i kompendium, wiarygodnie informującego zarówno o takich samych, jak i odmiennych tendencjach.

Niemieccy historycy poddali badaniom także bardziej oddalone od Rzeszy regiony i zaprezentowali po części pierwsze badania na ich temat, na przykład dotyczące Rumunii i Transnistrii ${ }^{40}$; na temat Łotwy pojawiły się ostatnio nawet trzy książki: oprócz szkicu o polityce nazistowskiej i jej instytucji ${ }^{41}$ Andrej Angrick i Peter Klein - dwaj najwybitniejsi znawcy Holokaustu w Europie Wschodniej

${ }^{37}$ Polen unter deutscher und sowjetischer Besatzung, 1939-1945, red. Jacek Andrzej Młynarczyk, Osnabrück: Fibre, 2009; Gewalt und Alltag im besetzten Polen 1939-1945, red. Jochen Böhler, Stephan Lehnstaedt, Osnabrück: Fibre, 2011.

${ }^{38}$ Debatę zamyka przedstawienie stanu badań: Robert Gerwarth, Stephan Malinowski, Der Holocaust als „kolonialer Genozid”? Europäische Kolonialgewalt und nationalsozialistischer Vernichtungskrieg, „Geschichte und Gesellschaft” 2007, nr 33, s. 439-466.

${ }^{39}$ Das „Großdeutsche Reich” und die Juden. Nationalsozialistische Verfolgung in den „angegliederten” Gebieten, red. Wolf Gruner, Jörg Osterloh, Frankfurt: Campus, 2010. Ważna publikacja na temat włączonego również do Rzeszy tzw. Sudetenland to: Jörg Osterloh, $\mathrm{Na}$ tionalsozialistische Judenverfolgung im Reichsgau Sudetenland. 1938-1945, München: Oldenbourg, 2006.

${ }^{40}$ Holocaust an der Peripherie. Judenpolitik und Judenmord in Rumänien und Transnistrien 1940-1944, red. Wolfgang Benz, Berlin: Metropol, 2009.

${ }^{41}$ Sven Jüngerkes, Deutsche Besatzungsverwaltung in Lettland 1941-1945. Eine Kommunikations- und Kulturgeschichte nationalsozialistischer Organisationen, Konstanz: Uvk, 2010. 
badający temat od strony sprawców - przedstawili historię getta w Rydze i jego likwidacji ${ }^{42}$. Chociaż obydwaj autorzy tylko sporadycznie sięgają do literatury łotewskiej, na podstawie ogromnej liczby źródeł wykazują sprzężenie ideologii i gospodarki, wyrażające się szczególnie w wykorzystywaniu żydowskich robotników przymusowych.

Z niecierpliwością można oczekiwać na przewidziane na 2011 r. studium Kathrin Reichelt ${ }^{43}$, zapowiadające spojrzenie na problem kolaboracji i udziału w Holokauście ludności nieżydowskiej. Ten aspekt ludobójstwa stanowi ciągle w dużym stopniu postulat badawczy. Znakomita praca zbiorowa Instytutu Północno-Wschodniego (Nord-Ost-Institut) w Lüneburgu daje tutaj ważne impulsy metodologiczne, ale mord na Żydach jest tylko częściowo jej tematem ${ }^{44}$. Bez kolaboracji i poparcia lokalnej ludności nie byłby możliwy do przeprowadzenia - albo przynajmniej nie w takiej formie. Trudność w naukowym roztrząsaniu integralnego fenomenu ludobójstwa, który ostatecznie zawiera również profity z wymordowania żydowskich współmieszkańców, polega na wyważonej ocenie udziału nieniemieckiego. Holokaust był projektem europejskim, ale wydarzył się pod panowaniem niemieckim, na niemiecki rozkaz i w warunkach nazistowskiej ideologii rasowej.

Tę trudność przekonująco przezwyciężyła Ruth Bettina Birn w swoim - dotychczas zbyt mało zauważanym - pionierskim studium poświęconym Estonii ${ }^{45}$. Dowiodła, że estońska policja bezpieczeństwa istniała jako równorzędny partner władz niemieckich i podejmowała działania także z własnej inicjatywy. Ponieważ Estończycy zajmowali bardzo wysokie miejsce w narodowosocjalistycznej hierarchii rasowej, rozwinęło się niemal równoprawne partnerstwo, aczkolwiek podporządkowane ideologicznym celom reżimu okupacyjnego. Co znamienne, niemieccy policjanci koncentrowali się na eksterminacji Żydów, natomiast Estończycy skupiali się szczególnie na komunistach.

Znacznie większe postępy niż w odniesieniu do zagadnienia kolaboracji uzyskano w ostatnich latach w badaniach dotyczących roli Wehrmachtu. Intensywne studia nad wojskiem, w których sięgnięto nawet do prezentowanej w latach 1995-1999 względnie 2001-2004 (w zmienionej formie) wystawy poświęconej Wehrmachtowi (tzw. Wehrmachtsausstellung), przynoszą pokaźne rezultaty. W omawianym okresie

${ }^{42}$ Andrej Angrick, Peter Klein, Die „Endlösung” in Riga. Ausbeutung und Vernichtung 1941-1944, Darmstadt: Wissenschaftliche Buchgesellschaft, 2006.

${ }^{43}$ Kathrin Reichelt, Lettland unter deutscher Besatzung 1941-1944. Der lettische Anteil am Holocaust, Berlin: Metropol, 2011.

${ }^{44}$ „Kollaboration” in Nordosteuropa. Erscheinungsformen und Deutungen im 20. Jahrhundert, red. Joachim Tauber, Wiesbaden: Harrassowitz, 2006. Interesujące przykłady, również w odniesieniu do innych aspektów Zagłady, zob. Besatzung, Kollaboration, Holocaust. Neue Studien zur Verfolgung und Ermordung der europäischen Juden, red. Johannes Hürter, Jürgen Zarusky, München: Oldenbourg, 2008.

${ }^{45}$ Ruth Bettina Birn, Die Sicherheitspolizei in Estland 1941-1944. Eine Studie zur Kollaboration im Osten, Paderborn-München: Schöningh, 2006. 
ukazała się przykładowo szczegółowa analiza rozkazu o komisarzach (Kommissarbefehl), przewidującego albo natychmiastowe rozstrzeliwanie wszystkich wziętych do niewoli komisarzy politycznych, ale również Żydów, albo przekazywanie ich SS, które mordowało ich w późniejszym czasie ${ }^{46}$. W wieloletnim projekcie badawczym na temat niemieckich generałów wykazano ponadto, że nie tylko zostali pozbawieni władzy przez Hitlera, lecz przyjęli to bez protestów i najpóźniej z początkiem agresji na Związek Radziecki wstrzymali się z krytyką zbrodniczej polityki, a nawet aprobowali mordy, których Wehrmacht sam miał dokonywać; skrupuły przy stosowaniu przemocy wobec Żydów i innych cywilów były absolutnym wyjątkiem ${ }^{47}$.

Oczywiście, sami generałowie nie strzelali, robili to członkowie jednostek wojskowych. Christian Hartmann poddał analizie zachowania tych ludzi ${ }^{48}$ : wyjątkowym okrucieństwem wobec Żydów odznaczały się szczególnie oddziały w głębi kraju, a zatem nie bezpośrednio na froncie. Należy zauważyć, że dla kwestii, czy ktoś stawał się mordercą, kluczowe były nie ideologizacja żołnierzy ani indoktrynacja narodowosocjalistyczna, ale często zupełnie banalne elementy kontekstu sytuacyjnego, takie jak miejsce stacjonowania, wykorzystanie jednostki bądź samodzielność dowódcy.

O ile obydwie wymienione prace pokazują perspektywę od górnych do dolnych szczebli, o tyle Dieter Pohl koncentruje się szczegółowo na strukturach okupacyjnych, które Wehrmacht tworzył w podbitym kraju po przejściu frontu ${ }^{49}$. Pohl pokazuje, w jakich warunkach dochodziło do aktów brutalnej przemocy, będących zresztą głównym obiektem jego badań; zaletą książki jest szerokie wykorzystanie literatury również rosyjsko- i polskojęzycznej oraz zaprezentowanie rozległej panoramy konkretnych wydarzeń, przy czym autor nie wychodzi jednak poza inne formy interakcji z okupowanymi niż przemoc.

Wehrmacht $\mathrm{w}$ tych wszystkich badaniach okazał się jednoznacznie i bezdyskusyjnie organizacją zbrodniczą, natomiast dotychczas nie pojawiły się takie ustalenia odnośnie do Ministerstwa Spraw Zagranicznych. Wprawdzie wkład ministerstwa w Holokaust był już wcześniej znany i niekiedy podejmowano temat obsadzania stanowisk ministerialnych byłymi nazistami po 1945 r., niemniej zważywszy na uprawianą w Republice Federalnej kulturę pamięci, stale domagającą się oficjalnych badań, nie potwierdzono tego jeszcze przez urzędową komisję

${ }^{46}$ Felix Römer, Der Kommissarbefehl. Wehrmacht und NS-Verbrechen an der Ostfront 1941/42, Paderborn-München: Schöningh, 2008.

${ }^{47}$ Johannes Hürter, Hitlers Heerführer. Die deutschen Oberbefehlshaber im Krieg gegen die Sowjetunion 1941/42, München: Oldenbourg, 2006.

${ }^{48}$ Christian Hartmann, Wehrmacht im Ostkrieg. Front und militärisches Hinterland 1941/42, München: Oldenbourg, 2010.

${ }^{49}$ Dieter Pohl, Die Herrschaft der Wehrmacht. Deutsche Militärbesatzung und einheimische Bevölkerung in der Sowjetunion 1941-1944, München: Oldenbourg, 2009. O dowódcach na tyłach frontu por. także Jörn Hasenclever, Wehrmacht und Besatzungspolitik in der Sowjetunion. Die Befehlshaber der rückwärtigen Heeresgebiete 1941-1943, Paderborn-München: Schöningh, 2010. 
historyczną ${ }^{50}$. Ta zaś orzekła, że do pewnego stopnia uprawnione jest określenie Ministerstwa Spraw Zagranicznych mianem organizacji zbrodniczej. W publikacji nie zaprezentowano istotnych nowych ustaleń, ale książka wywołała - właśnie ze względu na swój półoficjalny i zarazem ikwizytorski charakter - pewną sensację, jak również wiele krytyki, przede wszystkim wśród specjalistów. Z jednej strony ganiono jednostronne skupienie się na Zagładzie, w której Ministerstwo Spraw Zagranicznych w żadnym razie nie odegrało kluczowej roli - jak to po części formułuje dzieło komisji - z drugiej strony zarzucano pewną nierzeczowość, wskazując, że ogłaszane przez studium nowości to od dawna znane fakty. Podobnie jak to już wystapiło w debacie na temat wojskowego oporu, linia frontu przebiegała między historykami konserwatywnymi a raczej lewicowymi i ponownie ten nierzadko polemiczny spór nie okazał się dotychczas owocny naukowo. Z pewnością Das Amt und die Vergangenheit nie stanowi wielkiego osiągnięcia i ostatecznego dzieła podstawowego, pokazuje jednak, jakie poruszenie mogą wciąż wywoływać w Niemczech rzekome nowe odkrycia w sprawie Holokaustu.

Prawdziwie interesujące są natomiast rezultaty badań nad sprawcami (Täterforschung), a więc tymi, którzy dokonywali ludobójstwa. Są to w mniejszym stopniu klasyczne biografie, jakie w ostatnich latach ukazały się na temat Hansa Franka, Ericha Kocha lub „badacza Żydów” Petera-Heinza Seraphina ${ }^{51}$, napisane w ostatnim czasie przez historyków, przede wszystkim zaś - cieszące się już uznaniem - badania kierujące spojrzenie na większą liczbę sprawców. W centrum zainteresowania badaczy znaleźli się oczywiście przede wszystkim mężczyźni, nawet jeżeli Elissa Mailänder Koslov w pouczający sposób wykazała, że w obozie koncentracyjnym i zagłady na Majdanku również nadzorczynie działały z własnej inicjatywy i przyczyniały się do masowego mordu ${ }^{52}$. Inna kwestia, że pola działania, które pozostawiono kobietom, były przez nie wykorzystywane w większości tylko do tego, żeby postępować wobec więźniów z większą brutalnością, niż tego oczekiwano. Nie tylko z tego powodu ta nowatorska dysertacja stanowi pionierskie studium, włączające aspekty genderowe do badań nad Holokaustem, które nadal mają charakter bardzo opisowy i konwencjonalny.

Odnosi się to w szczególności do skrupulatnie zbadanych w ostatnim czasie jednostek policyjnych, których zbrodnie po agresji na Związek Radziecki pozostawiały za sobą niezliczonych zabitych. Obszerne dzieła źródłowe, dokumentujące głównie

\footnotetext{
${ }^{50}$ Das Amt und die Vergangenheit. Deutsche Diplomaten im Dritten Reich und in der Bundesrepublik, red. Eckart Conze i in., München: Karl Blessing Verlag, 2010.

${ }^{51}$ Dieter Schenk, Hans Frank. Hitlers Kronjurist und Generalgouverneur, Frankfurt am Main: Fischer 2006 (wyd. polskie: Hans Frank. Biografia generalnego gubernatora, tłum. Krzysztof Jachimczak, Kraków: Znak, 2009); Ralf Meindl, Ostpreußens Gauleiter. Erich Koch - eine politische Biographie, Osnabrück: Fibre, 2007; Hans-Christian Petersen, Bevölkerungsökonomie, Ostforschung, Politik. Eine biographische Studie zu Peter-Heinz Seraphim (19021979), Osnabrück: Fibre, 2007.

${ }^{52}$ Elissa Mailänder Koslov, Gewalt im Dienstalltag. Die SS-Aufseherinnen des Konzentrations- und Vernichtungslagers Majdanek, Hamburg: Hamburger Edition, 2009.
} 
na podstawie akt zachodnioniemieckiego aparatu ścigania zbrodnie popełnione w Komisariacie Rzeszy Wschód i na ziemiach polskich, albo właśnie opublikowano, albo ukażą się niebawem ${ }^{53}$, uzupełniając dane biograficzne zbrodniarzy oraz wysiłki sądownictwa powojennego, aby doprowadzić do ukarania winnych ${ }^{54}$. Znajdujące się w centrum zainteresowań badawczych kręgi sprawców obejmują wiele tysięcy ludzi i rzadko pozwalają na prawdziwe zaszeregowanie działań policjantów ${ }^{55}$.

Bardziej znacząca i perspektywiczna jest analiza mniejszych grup, opisująca również kontekst sytuacyjny, w którym zbrodnie się dokonywały względnie były przygotowywane. Socjolog Harald Welzer zademonstrował potencjał interpretacyjny takiego podejścia również w odniesieniu do policjantów działających w Europie Wschodniej ${ }^{56}$. Zalety takiego mikrostudium, zainspirowanego nowym podejściem, pokazuje na przykład Peter Klein, który w ważnej książce bada Gettoverwaltung Litzmannstadt (Zarząd Getta Łódzkiego) ${ }^{57}$. Łączy biografię tamtejszych najwyższych funkcjonariuszy z analizą działań administracyjnych, która wyraźnie uwypukla interesy ekonomiczne wokół getta w Łodzi. Książka Kleina przekonująco udowadnia, że w Kraju Warty to nie SS forsowała masowy mord, lecz administracja cywilna kierowana przez Arthura Greisera, który w ścisłej współpracy z Heinrichem Himmlerem przeprowadził likwidację getta - nie tyle z kalkulacji ekonomicznych, ile przede wszystkim z powodu konfliktów z zarządem miejskim.

Nieco większą liczbą sprawców zajmował się Markus Roth w swojej analizie poświęconej starostom powiatowym w Generalnym Gubernatorstwie, przy czym obalił on utrwalone poglądy o rzekomych antagonizmach między administracją i SS w czasie wojny, które dominowały w literaturze przedmiotu aż do początku lat dziewięćdziesiątych ${ }^{58}$. Mistrzowskie połączenie zagadnień biografii i faktów - w niemal 60-stronicowym aneksie starostów sportretowano pojedynczo - umożliwia prekursorskie ustalenia na temat przyczyn niemieckich zbrodni w Polsce. Ponadto Roth pokazuje na przykładach, jak nazistowskie powiązania egzystowały dalej w Republice Federalnej i umożliwiły integrację sprawców z powojennym

${ }^{53}$ Wolfgang Curilla, Die deutsche Ordnungspolizei und der Holocaust im Baltikum und in Weissrussland 1941-1944, Paderborn-München: Schöningh, 2006; idem, Der Judenmord in Polen und die deutsche Ordnungspolizei 1939-1945, Paderborn: Schöningh, 2011.

${ }^{54}$ Stefan Klemp, „Nicht ermittelt”. Polizeibataillone und die Nachkriegsjustiz. Ein Handbuch, Essen: Klartext, 2005.

${ }^{55}$ Wyjątek stanowi: Alexander Neumann, Petra Peckl, Kim Christian Priemel, Praxissemester „Osteinsatz”. Der Führernachwuchs der Sipo und der Auftakt zur Vernichtung der litauischen Juden, „Zeitschrift für Genozidforschung” 2006, nr 7, s. 8-48.

${ }^{56}$ Harald Welzer, Täter. Wie aus ganz normalen Menschen Massenmörder werden, Frankfurt am Main: Fischer, 2006 (wyd. polskie: Sprawcy. Dlaczego zwykli ludzie dokonuja masowych mordów, tłum. Magdalena Kurkowska, Warszawa: Scholar, 2010).

${ }^{57}$ Peter Klein, Die „Gettoverwaltung Litzmannstadt” 1940 bis 1944. Eine Dienststelle im Spannungsfeld von Kommunalbürokratie und staatlicher Verfolgungspolitik, Hamburg: Hamburger Edition, 2009.

${ }^{58}$ Markus Roth, Herrenmenschen. Die deutschen Kreishauptleute im besetzten Polen. Karrierewege Herrschaftspraxis und Nachgeschichte, Göttingen: Wallstein, 2009. 
społeczeństwem bez odbycia kary. Ich prawne ściganie, ujęte w większości wymienionych książek w formie krótszego lub dłuższego (obowiązkowego) rozdziału końcowego, zajmuje u Rotha jedną trzecią tekstu i prezentuje się jako organiczny element całościowej historii starostów, która mimo iż w 1945 r. doznała pęknięcia, wcale się nie zakończyła.

Przedmiotem mojej własnej pracy jest znacznie większa i bardziej różnorodna grupa mężczyzn i kobiet: okupanci w Warszawie i Mińsku5 ${ }^{59}$. Pokazuję, w jakich warunkach wielu Niemców aktywnie uczestniczyło w okupacji i masowym mordzie, i kreślę obraz społeczności okupantów, dnia powszedniego Niemców między zagospodarowanym odgórnie czasem wolnym a indywidualną swobodą, nielubianą służbą w Europie Wschodniej a możliwością występowania w roli „władców”. Okupanci rozwinęli pewien wzorzec postaw, zgodnie z którym postrzegali siebie jako nowych panów na Wschodzie, górujących nad miejscową ludnością - chociaż ta stanowiła zarazem zagrożenie, które należało poważnie traktować. Tylko okupanci mieli prawo korzystać z wszelkich przyjemności i tylko oni mieli mieszkańców zajętych terenów do dyspozycji. W praktyce oznaczało to, że Niemcy mogli sobie pozwolić niemalże na wszystko, ofiary znajdowały się po stronie miejscowej ludności, a zbrodnie nie budziły poruszenia. Dyskrecja w działaniu była bezpośrednio związana z wizerunkiem „panów”, którzy nie okazywali żadnej słabości. Właśnie $\mathrm{z}$ tego powodu stosowanie przemocy było w znacznym stopniu akceptowane, ponieważ wydawało się, że pozwala tylko demonstrować własną przewagę i zarazem potwierdzać wśród lokalnej ludności jej niższość. Od tych i innych ideologicznie i ekonomicznie uwarunkowanych czynników samousprawiedliwiania własnych działań była już krótka droga do legitymizacji przemocy, która ostatecznie ukazała masowy mord na Żydach jako coś niemal oczywistego.

Trend, by prowadzić analizy badawcze zawężone do jednego miejsca lub regionu, co pozwala na drobiazgowe opisanie mniejszych obszarów, trwa nieprzerwanie. W następnych latach należy się spodziewać kilku dysertacji na temat poszczególnych miast i ich losów, których cezury wyznaczyły początek i koniec wojny. W przeciwieństwie do tych zarówno licznych, jak i owocnych badań nad historią struktur i sprawców, studia niemieckich historyków poświęcone samym prześladowanym wypadają dość mizernie. W ostatnich latach z zainteresowaniem spotkało się głównie getto łódzkie ${ }^{60}$. Ukazał się wówczas nie tylko zbiór fotografii ${ }^{61}$, lecz

${ }^{59}$ Stephan Lehnstaedt, Okkupation im Osten. Besatzeralltag in Warschau und Minsk 1939-1944, München: Oldenbourg, 2010. Polski przekład ukaże się w 2011 r. w Wydawnictwie Naukowym PWN.

${ }^{60}$ Opis małych gett zob. Im Ghetto 1939-1945. Neue Forschungen zu Alltag und Umfeld, red. Christoph Dieckmann, Göttingen: Wallstein, 2009.

${ }^{61}$ Das Gesicht des Gettos. Bilder jüdischer Photographen aus dem Getto Litzmannstadt 1940-1944, red. Ingo Loose, Thomas Lutz, Berlin: Stiftung Topographie des Terrors, 2010. 
także Kronika getta, prowadzona na zarządzenie Judenratu przez jego Wydział Historyczny. To kluczowe źródło na temat Holokaustu opublikowano w dwóch pięciotomowych rzetelnych edycjach, po polsku i po niemiecku, i zasługują one na miano „ostatecznych”62.

W odniesieniu do Łodzi należy wymienić przede wszystkim wybitną dysertację Andrei Löw ${ }^{63}$, której znaczenie jest nie do przecenienia. To opracowanie stanowi pierwszą od wielu lat niemiecką rozprawę poświęconą ofiarom w Europie Wschodniej, a dzięki szerokiej recepcji polskich i żydowskich źródeł autobiograficznych metodologicznie przekonującą analizę, ukazującą codzienną walkę o przeżycie w ujęciu chronologicznym i tematycznym. Główną inspiracją książki jest niezmienne przeświadczenie, że Żydzi bynajmniej nie byli tylko pasywnymi ofiarami, ale wykazywali olbrzymią wolę kształtowania swojego życia, co należałoby koniecznie zbadać także na innych przykładach. Publikując w tym roku wspólnie z Markusem Rothem książkę na temat krakowskich Żydów, Löw będzie musiała zmierzyć się swoją własną miarą ${ }^{64}$.

Postulat badań nad prześladowanymi zrealizowano ostatnio w pracy zbiorowej poświęconej gettu białostockiemu, w której zaprezentowano nie tylko protokoły i obwieszczenia Judenratu, lecz także wyniki konferencji naukowej ${ }^{65}$. Wydawcy przedstawiają nowe ustalenia odnośnie do rad żydowskich na trzech płaszczyznach, ilustrują podejmowaną przez nich problematykę przykładami opublikowanych dokumentów i pytają na końcu o wartość poznawczą źródeł żydowskich do badania historii gett $\mathrm{w}$ okupowanej Polsce. W związku z tym zajmują się między innymi materiałami autobiograficznymi pozostawionymi przez Adama Czerniakowa i Chaima Rumkowskiego. Wszystko to przeprowadzone jest na najwyższym poziomie, co ponownie dowodzi, że funkcjonujący w Niemczech pogląd, jakoby historia ofiar niczego nie mogła wnieść do zrozumienia narodowego socjalizmu i Holokaustu, stracił tymczasem na aktualności ${ }^{66}$.

Kolejnych impulsów, które niebawem powinny znaleźć odbicie w publikacjach, należy spodziewać się po badaniach nad emeryturami za pracę w gettach, tzw. Ghettorenten. Niemieckie państwo uznało w 2002 r. możliwość otrzymania emerytury za wykonywaną w getcie pracę. Realizacja tych dyrektyw okazała się jednak wysoce

${ }^{62}$ Die Chronik des Gettos Lodz, Litzmannstadt, red. Sascha Feuchert i in., Göttingen: Wallstein, 2007; Kronika getta łódzkiego/Litzmannstadt Getto 1941-1944, t. 1-5, red. Julian Baranowski i in., Łódź: Archiwum Państwowe, 2009.

${ }^{63}$ Andrea Löw, Juden im Getto Litzmannstadt. Lebensbedingungen, Selbstwahrnehmung, Verhalten, Göttingen: Wallstein, 2010. Polski przekład ma się ukazać w 2012 r.

${ }^{64}$ Andrea Löw, Markus Roth, Juden in Krakau unter deutscher Besatzung 1939-1945, Göttingen: Wallstein, 2011.

${ }^{65}$ Der Judenrat von Białystok. Dokumente aus dem Archiv des Biatystoker Ghettos 19411943, red. Freia Anders, Katrin Stoll, Karsten Wilke, Paderborn: Schöningh, 2010.

${ }^{66} \mathrm{Na}$ temat tych tradycyjnych wzorców myślowych i interpretacyjnych zob. Nicolas Berg, Der Holocaust und die westdeutschen Historiker. Erforschung und Erinnerung, Göttingen: Wallstein, 2003. 
skomplikowana, tak że do postępowań prawnych włączono również historyków ${ }^{67}$. Opublikowano pierwsze rezultaty ich prac, jeszcze $\mathrm{w}$ formie ekspertyz dla sądów społecznych $^{68}$. Ponadto Instytut Północno-Wschodni w Lüneburgu zorganizował w 2009 r. konferencję „Lebenswelt Ghetto” (Świat getta), a wygłoszone tam referaty mają się ukazać w tomie zbiorowym, podobnie jak referaty z konferencji „Arbeit in nationalsozialistischen Ghettos" (Praca w narodowosocjalistycznych gettach), zorganizowanej w 2010 r. przez Niemiecki Instytut Historyczny wraz z Żydowskim Instytutem Historycznym.

Z języka niemieckiego przełożyła Agnieszka Lenarczyk

${ }^{67}$ Ghettorenten. Entschädigungspolitik Rechtsprechung und historische Forschung, red. Jürgen Zarusky, München: Oldenbourg, 2010.

${ }^{68}$ Jan-Henrik Peters, Zwischen Lohnarbeit und Deportation. Juden bei der Ostbahn im Generalgouvernement 1939-1943, „Zeitschrift für Geschichte” 2010, nr 58, s. 816-837. Dwie moje ekspertyzy dotyczące pracy przymusowej Żydów na wschodzie Górnego Śląska i w Kraju Warty ukazały się w 2010 r. w języku angielskim: Stephan Lehnstaedt, Coercion and Incentive. Jewish Ghetto Labor in East Upper Silesia, „Holocaust and Genocide Studies” 2010, nr 24, s. 400-430; idem, Jewish Labor in the Smaller Ghettos in the Warthegau Region, „Yad Vashem Studies” 2010, t. 38, nr 2, s. 47-84. 